\title{
Floral Sources for Stingless Bees (Tetragonula iridipennis) in Nellithurai Village, Tamilnadu, India
}

\section{K. Vijayakumar, R. Jeyaraaj}

Department of Zoology, Kongu Nadu Arts and Science College, Coimbatore, Tamil Nadu, India

Study Area: Nellithurai Village, Tamilnadu, India Coordinates: $11^{\circ} 1^{\prime} 59.74^{\prime \prime} \mathrm{N} \& 76^{\circ} 53^{\prime} 6.24^{\prime \prime} \mathrm{E}$

Key words: Bee flora, Non-floral sources, Melissopalynology, Meliponiculture.
Abstract

We documented 45 plant taxa belonging to 29 families and non-floral sources utilized by Tetragonula iridipennis for pollen, nectar and resin. The foragers of $\mathrm{T}$. iridipennis were also found to collect non-floral resources like fruit juice, fruits kept in the market for sales and from falling and damaged mango and jasmine fruits. The mutualistic association between $T$. iridipennis colonies and Hemipterans was observed and documented. According to pollen analysis, all are appeared to be multifloral honeys. The families Arecaceae and Fabaceae had a significant importance amongst the samples represented by four pollen types. Coconut, Sunflower and Banana pollen types occurred most constantly among the samples. The present palynological analysis of honey samples can provide the accurate depiction of the bee flora in Nellithurai village. The present study to help the beekeepers to know the stingless bee flora and to identify the botanical origins of honey.

of vegetation such as natural forests, grasslands, agricultural land, pasture land, or urban areas. Most of the methods for obtaining information about bee plants in an area are based on direct field observation of foraging bees on flowers. Absy \& Kerr (1977) using pollen analysis of honey began the study of stingless bee floral visitation in the Amazon region, which comprises different forest types, namely savannas and riversides including humandisturbed landscapes and urban areas. In Brazil, Oliveira et al. (2009) demonstrated that stingless bees are using varity of pollen resources, but they are not commonly utilized the unique plant species. The analysis of bee plant pollen loads and palynological analysis of honey samples can provide the accurate depiction of the bee flora of a particulararea/landscape (Lakshmi, 2012).

The melissopalynological studies of stingless bee honey are rare, limited to Melipona seminigra merrillae and Melipona rufiventris paraensis (Absy \& Kerr 1977), Melipona compressipes, Melipona favosa, Melipona trinitatis, Frieseomelitta nigra, Frieseomelitta sp. aff. varia, Plebeia sp., Scaptotrigona sp. aff. depilis , Scaura latitarsis and T. angustula (Vit et al. 1994), Melipona scutellaris (Carvalho et al, 2001), Melipona mandacaia (Alves et al. 2006 ), Tetragonisca angustula (Flores \& Sanchez 2010), and M. favosa (Vit et al. 2012). In India, significant work

Studies have been made in areas harbor different types

*Corresponding Author: knvijgs@gmail.com 
has been carried out by various authors (Ramanujam et al., 1992; Bhargava et al., 2009 \& Shilpa \& Ratan, 2011). Melissopalynology of Syzygium honey has been studied by Suryanarayana (1966) and Bhargava et al. (2009). Foraged pollen loads are good indicators of the surrounding flowering plant species that provide pollen for the bees. They also indicate availability of dominant food resources for the different pollinators in an ecosystem. The purpose of this study has been to use two different methods to identify the plant species visited most frequently by $T$. iridipennis.

\section{Materials and methods:}

Study Area: The study was carried out in the Nellithurai village of Coimbatore district, Tamil Nadu, India. Field observations were conducted between April 2013 to March 2014. In situ identification of plants visited by stingless bee forages was done by direct observation in the field. The bee floral survey carried out during peak foraging activity (6.oo am - $6.00 \mathrm{pm})$. Plant species were considered attractive to bees when they were observed to visit by more than five bees during a particular time interval (10 $\mathrm{min}$ ). The identification of pollen, nectar and resin foragers visually based on either pollen or resin load on corbiculae and honey stomach. The forager bees were caught with sweep nets and preserved for further studies.

Melissopalynological study: Present melissopalynological investigation was carried out in 15 different honey samples collected from different hived colonies of Tetragonula iridipennis located at Nellithurai village, Tamil Nadu, India. Pollen slides of honey samples were prepared using the method of Loureaux et al. (1978) and acetolysis (Erdtman, 1960). The pollen grains obtained from honey samples were identified and compared with the reference slides made from identif ied plants and from standard works of Erdthman (1960) and Lakshmi (2012). The absolute pollen count and percentages of pollen types in each sample were calculated (Lakshmi, 2012) on the basis of total number of pollen grains counted in each sample. Samples were observed using light and polarized light microscopy.

The pollen spectra were constructed on the basis of these percentages. Honey samples having $45 \%$ or more grains of a single pollen type were termed as "unifloral honey" and those having several pollen types in considerable percentage were termed as "multifloral honey". Frequencies and frequency classes of the pollen types were determined in accordance with Louveaux et al.(1978) and the pollen types were placed under four pollen frequency classes (Predominant pollen D (Above $45 \%)$, Secondary pollen S (16\% to $45 \%)$, Important minor pollen - IM (3\% to $15 \%$ ), Minor pollen m (Less than $3 \%)$ ) recommended by the International Commission for Bee Botany (ICBB) (Moore \& Webb, 1978).

\section{Results}

\section{Beefloral survey}

Predominant families of flowering plants in the study area: A total of 45 plant species belonging to 28 families were recorded. The important flowering families were Arecaceae and Fabaceae representing the highest frequency of $4(8.89 \% \quad \mathrm{~N}=45)$, Cucurbitaceae, Euphorbiaceae, Poaceae and Solanaceae with frequency of $3(6.67 \% \quad \mathrm{~N}=67)$, Lamiaceae and Rutaceae with frequency of $2(4.44 \% \mathrm{~N}=45)$ and remaining 20 families (Amaranthaceae, Anacardiaceae, Apiaceae, Apocynaceae, Calenduleae, Commelinaceae, Convolvulaceae, Lythraceae, Malvaceae, Meliaceae, Moringaceae, Musaceae, Myrtaceae, Nyctaginaceae, Phyllanthaceae, Portulacaceae, Rubiaceae, Verbenaceae, Vitaceae and Zygophyllaceae) with frequency of 1 (2.22\% $\mathrm{N}=45$ ) (Figure: 1).

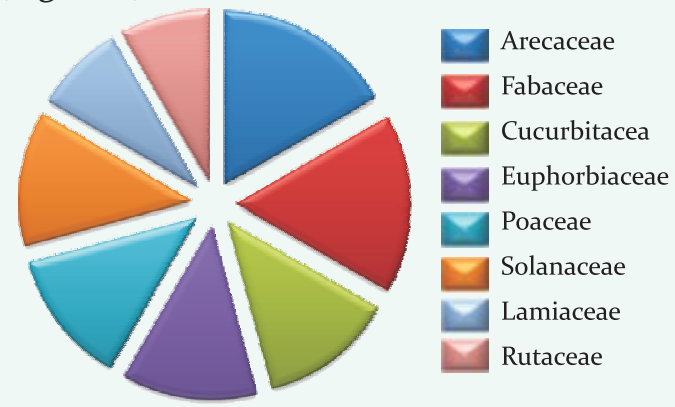

Figure 1. Important families of floral resources utilized by $T$. iridipennis

Extra-floral nectarines and non- floral resources: honeydew produced by sap-sucking Homoptera is an important resource for a variety of organisms. The foragers of T. iridipennis were also found to collect nonfloral resources like fruit juice, fruits kept in the market for sales and from falling and damaged mango and jasmine fruits. Foragers of T. iridipennis were also found to collect sugar sap from leaf nectaries (Plate 1a), sugar cane sap from crushed sugarcane stems (Plate $1 \mathrm{~b}$ ), watermelon juice and coconut neera. The foragers collected honey dew actively from papaya mealy bug (Paracoccus marginatus) (Plate 1c). The forager of T. iridipennis collects fresh resin from falling flowers (Plate $1 \mathrm{~d}$ ) and tree wounds. The forager of $T$. iridipennis were observed landing on mealybug assemblages and ingesting excess honeydew and bees were found to collect the honeydew from the mealy bug in the morning and late afternoon during observation times.

Melissopalynological study: melissopalynological investigations carried out on 15 honey samples collected from hived T. iridipennis colonies and indicated that the bees were found to forage on 45 pollen types belonging to 29 families for pollen, nectar and resin. The pollen micrograph was showed in plate 2. During this study, the pollen samples are taken from 15 hived T. iridipennis 


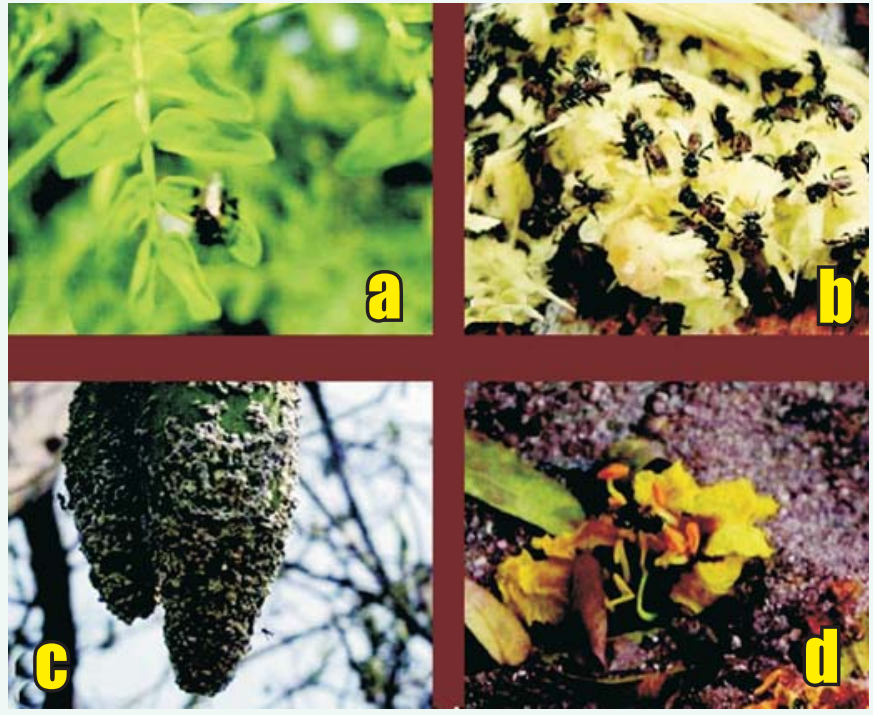

Plate 1: T. iridipennis collecting - a) nector from leaf, b) from crushed sugercane, c) excretes from animal waste, d) resin from falling flowers

colonies on April 2013 to March 2014 and were subjected to microscopicanalysis.

Results from the palynological studies show that stingless bees collect pollen from a wide range of plant species. Pollen grains of Cocus nucifera, Helianthus annuls and Musa paradisiaca were identified as a secondary pollen group. The important minor pollen groups (IM) and minor pollen groups (m) tabulated in table 3. Other plants were also visited by $T$. iridipennis are Alternanthera sessilis, Tamarindus indica, Helianthus annuls, Cajanus cajan, Citrus medica.Calotropis gigantean, Parthenium hysterophorus, Pongamia pinnata, Azadirachta indica, Aerva tomentosa, Digera muricata, Evolvulus alsinoides, Mimosa pudica, Jatropha curcas, Phyllanthus emblica, Capsicum frutescens, Eucalyptus sp., Soalnum melongena, Mangifera indica, Benincasa hispida, Prisopis julifera and Sorghum halepense. The lowest pollen frequency of 11 to 20 was noted in Vitex negundo, Coriandrum sativum, Tribulus terrestris and Pennisetum americanum.

\section{Discussion:}

Floral sources and non flora sources for stingless bees: the present study site located near the Nilgiri Biosphere Reserve located within the Western Ghats and is a region having high ecological and sociological importance (Prabhakar, 1994). Recently, Sasidharan \& Kunhikannan (2010) recorded 113 plant species belonging to 93 genera and 42 families which associated with bees in the Nilgiri Biosphere Reserve. During the study, a total of 45 plant species of 12 families was recorded at the source of Pollen/nectar/resin for stingless bees (T. iridipennis). The plant species found in agricultural fields are of great economic importance. Results showed that the stingless

bee-flora consists of mostly timber, medicinal, fruits, vegetables, ornamentals and other commercially important plants like pulses, cereals, oil yielding, fiber, fodder etc. Multivarious of the economic importance of the bee plants must be protected.

Honeydew produced by sap-sucking Homoptera is an important resource for a variety of organisms. In the present study, the mutualistic association between $T$. iridipennis colonies and Hemipterans was observed and documented. The forager bees found to collect the honeydew from the mealy bug. Similarly, the association between Hemipterans and stingless bees were discussed by Camargo \& Pedro (2002) and found only the genus Schwarzula had mutualistic association with Hemipterans. Roubik (1989) observed the mutualistic association between stingless bees and Hemipterans. In addition, some species of stingless bees with obligate nacrophagic habits, three species (Trigona necrophaga, T.hypogea and T.crassipes) were found to collect flesh of dead animals is their only protein source and sugars obtained from ripe or rotting fruit, extra floral nectaries, fallen flowers on the ground (Roubik, 1982).

Melissopalynological study: the results of the pollen analyses reveals that the forages of T. iridipennis are mostly preferred the 12 plants species belonging to four familes (Asteraceae, Musaceae, Fabaceae and Poaceae). The highest frequency ( 71 to $100 \%$ ) was noted in pollen of Cocus nucifera, Zea myze, Musa paradisiaca and Commelina benghalensis. The presence of the above pollen types were noted annually, which confirmed the attractiveness of their pollen and nectar to stingless bees.

Similarly, Singh \& Kar (2011) recorded a diverse spectrum of 27 pollen types belonging to 19 families from 12 Sunderbans honey samples (Bangaldesh) and Andaman (India). Jhansi et al. (1994) recorded 51 pollen types referable to 36 families in the samples studies from Andhra Pradesh, India. Atwal et al. (1970) studied different bee flora for four species of Apis mellifera for Lucknow region based on the pollen analysis. Recently, Padmavathy \& Rehel (2014) recorded 12 species belonging

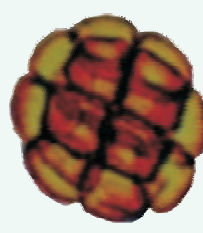

Acacia torta

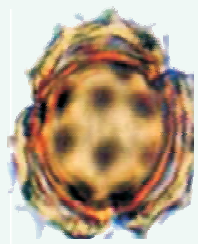

Parthenium sp. Tamarindus indica Mimosa pudica Mimosa pudica Plate 2: Pollen micrographs
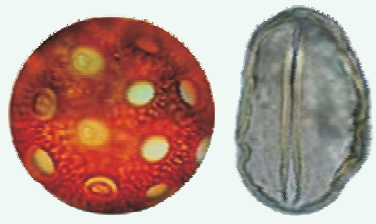

Alternanthera sp. Cocus nucifera Cocus nucifera
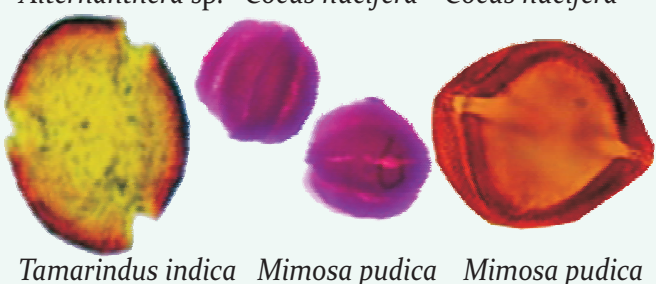
Vol.-03(2): p. 71 
to 11 families were identified as floral sources for Apis dorsata in Conoor, Nilgiri hills, Tamil Nadu. They recorded the pollen grains of Syzygium cumini and Acacia spp. frequently from the honey samples of $A$.dorsata.

A pollen spectrum reveled that the pollen grains of Cocus nucifera as a major source of pollen and it was found throughout the year in the present study area. Similarly, Bhargava et al. (2009) reported that Cocus nucifera as the pollen source available throughout the year in Karnataka, India. In addition, Sekhar (200o) revealed that the dominant pollen sources for bees in Bangaluru region are also Cocus nucifera and Eucalyptus tereticornis. Many Asteraceae species produce nectar (Terrab et al., 2001) and according to our results the taxa of this family are of great importance both as nectar and pollen source in the study area. In addition, Suryanarayana et al. (1991) in their study at Muzaffarpur (Bihar), India, reported that members of Asteraceae provided forage for a major part of theyear.

The present study confirmed the availability of high diversity vegetation around Nellithurai village. In addition, melissopalynology of stingless bee honey helps to characterize vegetation surrounding the collection site and provide detailed information on stingless bee flowering plants. The present study helps the beekeepers and farmers to know the flowering plants utilized by stingless bees. Thus they can take appropriates steps to develop meliponiculture.

Acknowledgements:We are grateful to Dr. Cleofas R. Cervancia, for her guidance during the study. We are especially indebted to Dr. Deborah Smith (University of Kansas, USA) for identifying stingless bee species and providing relevant literature. I extend my sincere thank to Dr. M. Muthuraman, for his encouragement and motivation to pursue the research work. I would also like to thank to beekeeper Mr. G.K. Thangavelu for sample collection and documentation.

\section{References:}

Absy, M.L. \& Kerr, W.E. (1977): Algumas plantas visitadas para obtencao de pólen por operarias de Melipona seminigra merrillae em Manaus. Acta Amazonica, 7:309-315.

Alves, R.M.O., Carvalho, C.A.L. \& Souza, B.A. (2006): Espectro polínico de amostras de mel de Melipona mandacaia Smith, 1863 (Hymenoptera: Apidae). Acta Scientiarum Biol.Sci. 28: 65-70.

Atwal, A.S., Bains, S.S. \& Singh, B. (1970): Bee flora for four species of Apis at Ludhiana. Ind. J. Entomol., 32:330-334.

Bhargava, H.R., Jyothi, J.V.A., Bhushanam, M. \& Surendra, N.S. (2009): Pollen Analysis of Apis honey, Karnataka, India. APIACTA, 44:14- 19.

Camargo, J.M.F. \& Pedro, S.R.M. (2002): Mutualistic association between a tiny Amazonian stingless bee and wax producing scale insect. Biotropica, 34: 1-6.

Carvalho, C.A.L., Moreti, A.C.C.C., Marchini, L.C., Alves, R.M.O., \& Oliveira, P.C.F. (2001): Pollen spectrum of honey of "uruçu" bee (Melipona scutellaris). Rev. Brasil.de Biol., 61: 63-67.
Erdtman, G. (1960): TheAcetolysis MethodA Revised Description'. Svensk. Bot.Tidskr., 54:561-564.

Flores, F.F. \& Sanchez, A.C. (2010): Primeros resultados de la caracterización botánica de mieles producidas por Tetragonisca angustula (Apidae, Meliponinae) en Los Naranjos, Salta, Argentina. Boletín de la Sociedad Argentina de Botánica, 45: 81-91.

Jhansi, P., Kalpana, T.P. \& Ramanujam, C.G.K. (1993): Pollen analysis of some Apis cerana honeys from Andhra Pradesh, India. Apidologie, 25:289-296.

Kerr, W.E., Carvalho, G.A., Silva, A.C. \& Assis, M.G.P. (2001): Aspectos pouco mencionados sobre a biodiversidade da Amazonia. Le journal du Parc est paru, 12: 20-41.

Kumar, M.S., Singh, A.J.A.R. \& Alagumuthu, G. (2012): Traditional beekeeping of stingless bees (Trigona sp.) by Kani tribes of Western Ghats, Tamil Nadu, India. Ind. J. Tradit. Know., 11: 342-345.

Lakshmi, K. (2012): Melissopalynology: A training manual prepared for a special training in Melissopalynology organized by Central Bee Research and Training Institute, Pune. p1-20.

Louveaux, J., Maurizio, A. \& Vorwohl, G. (1978): Methods of Melissopalynology. Bee World, 59:39-157.

Moore, P.D., \& Webb, J.A. (1978): An illustrated guide to pollen analysis. Hodder and Stoughton Publisher, London. pp 1-121.

Oliveira, F.P.M., Absy, M.L. \& Miranda, I.S. (2009): Recurso polínico coletado por abelhas sem ferrao (Apidae, Meliponinae) em um fragmento de $\mathrm{fl}$ oresta na regiao de Manaus-Amazonas. ActaAmazonica, 39: 505-518.

Padmavathy, M. \& Rehel, S.M. (2014): Bee Plants of Apis dorsata during Winter Season from Coonoor Region, Nilgiris, Tamil Nadu, India. L. Acad. Ind. Res., 2: 570- 572.

Prabhakar, R. (1994): Resource use, culture and ecological change: A case study of the Nilgiri hills of southern India. Ph.D thesis, submitted to Indian Institute of Science, Bangalore.p 178.

Ramanujam, C.G.K., Kalpana, T.P. \& Fatima, K. (1992): Mellittopalynology and recognition of major nectar and pollen sources for honeybee in some districts of Andhra Pradesh. Geophytol, 22: 261-271.

Roubik, D.W. (2006): Stingless bee nesting biology. Apidologie, 37: 124-143.

Roubik, D.W. (1989): Ecology and natural history of tropical bees. Roubik D.W. (Eds.), Cambridge University Press, New York. p 514.

Roubik, D.W. (1982): Obligate necrophagy in a social bee. Science 217: 1059-106o.

Sasidharan, K.R. \& Kunhikannan, C. (2010): Bee faunal diversity in the Nilgiris part of the Western Ghats, Tamil Nadu. In: Raju A.J.U. (Eds.), Ecology of pollen and fungal spore. pp 1-16.

Sekhar, P. (2000): Melissopalynological studies of Apis cerana indica Fab. in Bagaluru region. M.Sc. Thesis. University of Agricultural Sciences, Bangaluru, India.p 72.

Shilpa, S. \& Ratan, K. (2011): Melissopalynological studies in Mangroove honey from Sundarbans (Bangladesh). Curr. Sci., 100(8): 1290-1293.

Singh, S. \& Kar, R. (2011): Melissopalynology studies on mangrove honeys from Sunderbans (Bangladesh) and Little Andaman 
(India). Birbal Sahni Institute of Palaeobotany, Lucknow, India. Cur. Sci., 100:1290-1293.

Suryanarayana, M.C., Rao, M.G., \& Singh, T.S.M.S. (1991): Studies on pollen sources for Apis verana and Apis mellifera bees at Muzaffarpur, Bihar, India.Apidologie, 23:33-46.

Suryanarayana, M.C. (1966): Studies on flora of Coorg with emphasis on beekeeping forage plants, Ecological and Botanical Features. Ind. Bee I., 28: 59-75.

Terrab, A., Diez, M.J. \& Heredia, F.J. (2003): Palynological, Physicochemical and Colour Characterisation of Moroccan Honeys. I. River Red Gum (Eucalyptus camaldulensis) Honey. Int. J. Food Sci. Technol., 38:379-386.
Vijayakumar, K., Muthuraman, M. \& Jayaraj, R. (2013): Propagating Trigona iridipennis colonies (Apidae: Meliponini) by Eduction method. Schol. Acad. J. Bio., 1:1-3.

Vit, P., Ricciardelli, D. \& Albore, G. (1994): Melissopalynology for stingless bees (Hymenoptera: Apidae: Meliponinae) in Venezuela.J.Apicul. Res., 33:145-154.

Vit, P., Mejias, A., Rial, L., Ruíz, J., Pena, S., Gonzalez, A.C., Rodríguez-Malaver, A., Arraez, M., Gutierrez, C., Zambrano, A. \& Barth, O.M. (2012): Conociendo la miel de Melipona favosa en la Península de Paraguana, Estado Falcón, Venezuela. Revista del Instituto Nacional de Higiene Rafael Rangel, 43:1519.

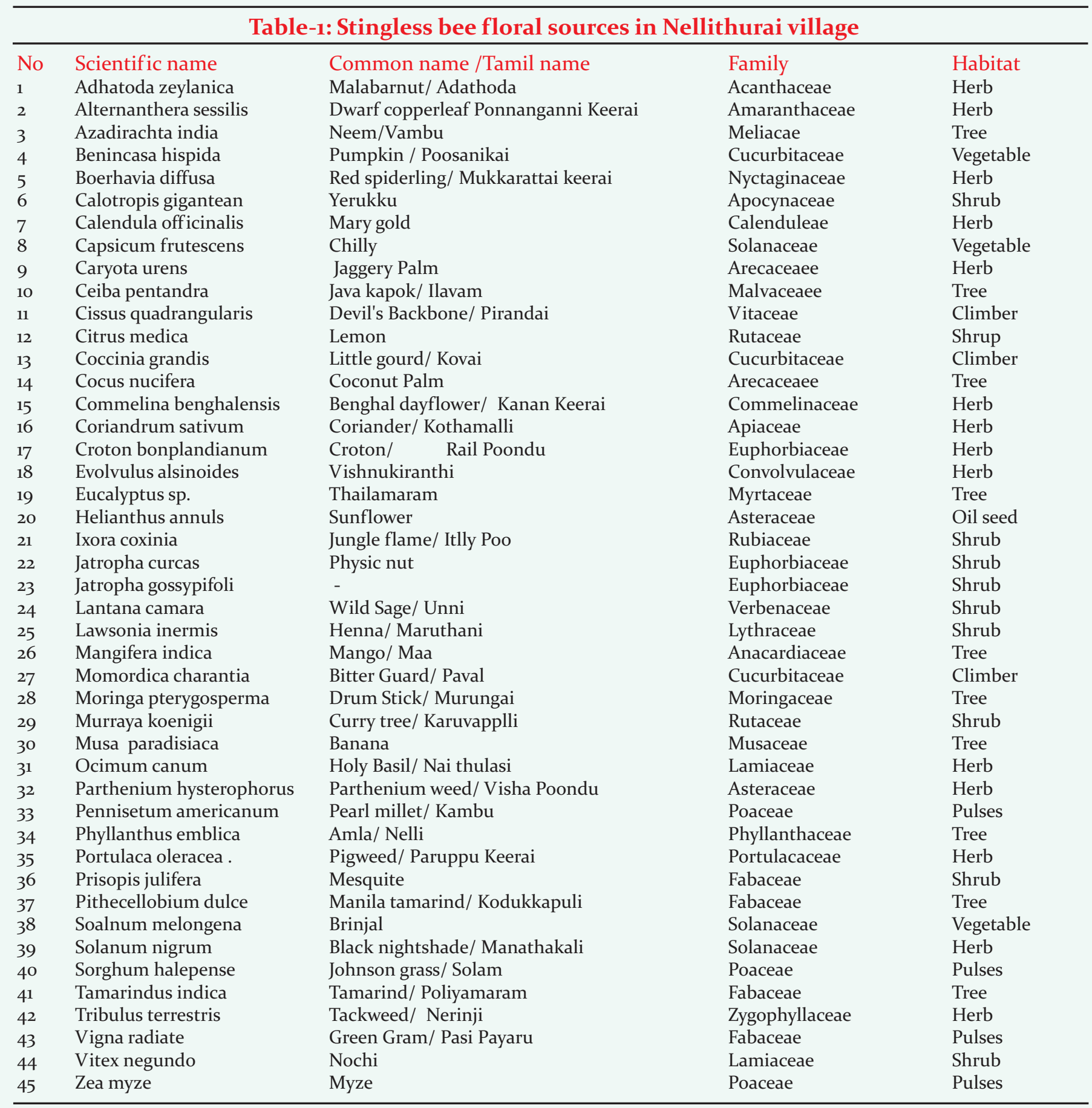

Ambient Science (2016) 
Table-2: Important pollen groups in the study area and their frequency

\begin{tabular}{|c|c|c|c|c|c|c|}
\hline S.No & Family & Pollen type & $\mathrm{S}$ & IM & M & $\mathrm{FO}^{*}$ \\
\hline 1 & Acanthaceae & Aerva tomentosa & & & 5 & 33.30 \\
\hline 2 & & Alternanthera sessilis & & & 10 & 66.70 \\
\hline 3 & & Digera muricata & & & 6 & 40.00 \\
\hline 4 & Anacardiaceae & Mangifera indica & 1 & 3 & & 26.60 \\
\hline 5 & Apiaceae & Coriandrum sativum & & 2 & 1 & 20.00 \\
\hline 6 & Apocynaceae & Calotropis gigantean & & 6 & 1 & 46.67 \\
\hline 7 & Asteraceae & Cocus nucifera & 12 & 2 & 1 & 100.00 \\
\hline 8 & & Helianthus annuls & 6 & 3 & & 60.00 \\
\hline 9 & & Parthenium hysterophorus & 3 & 2 & 2 & 46.67 \\
\hline 10 & & Tridax procumbens & & 1 & 5 & 40.00 \\
\hline 11 & Commelinaceae & Commelina benghalensis & & & 11 & $73 \cdot 33$ \\
\hline 12 & Convolvulaceae & Evolvulus alsinoides & & & 5 & $33 \cdot 30$ \\
\hline 13 & Euphorbiaceae & Croton bonplandianum & & & 3 & 20.00 \\
\hline 14 & & Jatropha curcas & & 4 & 2 & 40.00 \\
\hline 15 & Fabaceae & Cajanus cajan & & 5 & 3 & 53.33 \\
\hline 16 & & Pongamia pinnata & & 4 & 3 & 46.67 \\
\hline 17 & & Mimosa pudica & & & 4 & 26.60 \\
\hline 18 & & Tamarindus indica & 2 & 5 & 3 & 66.70 \\
\hline 19 & Lamiaceae & Vitex negundo & & 1 & 1 & $13 \cdot 33$ \\
\hline 20 & Meliaceae & Azadirachta indica & 6 & & 1 & 46.67 \\
\hline 21 & Myrtaceae & Eucalyptus sp. & & 2 & 2 & 26.60 \\
\hline 22 & Musaceae & Musa paradisiaca & 7 & & 4 & $73 \cdot 33$ \\
\hline 23 & Phyllanthaceae & Phyllanthus emblica & 1 & 4 & & $33 \cdot 33$ \\
\hline 24 & Poaceae & Pennisetum americanum & & & 3 & 20.00 \\
\hline 25 & & Sorghum halepense & & 4 & & 26.60 \\
\hline 26 & & Zea myze & 7 & 3 & 2 & 80.00 \\
\hline 27 & Rutaceae & Citrus medica & 3 & 1 & 4 & $53 \cdot 33$ \\
\hline 28 & Solanaceae & Capsicum frutescens & 1 & 5 & & 40.00 \\
\hline 29 & & Soalnum melongena & & 6 & & 40.00 \\
\hline 30 & Zygophyllaceae & Tribulus terrestris & & 3 & & 20.00 \\
\hline
\end{tabular}

*Frequency observation 